\title{
Genetic diagnosis in hypertrophic cardio- myopathy: two steps forward, one step back
}

\author{
Lidia Hategan, Beáta Csányi, János Borbás, Eszter Dalma Pálinkás, \\ Hedvig Takács, Viktória Nagy, Róbert Sepp
}

University of Szeged, Faculty of Medicine, Department of Internal Medicine and Cardiology Center, Szeged

Levelezési cím:

Prof. dr. Sepp Róbert, Szegedi Tudományegyetem, Belgyógyászati Klinika, Non-Invazív Kardiológiai Részleg

6725 Szeged, Semmelweis u 8. E-mail: sepprobert@gmail.com

Hypertrophic cardiomyopathy (HCM) is the most common genetic cardiovascular disorder worldwide which exhibits considerable genetic heterogeneity. Widespread utilization of next-generation sequencing (NGS) in HCM has uncovered substantial genetic variation and highlighted the importance of a standardized approach to variant interpretation. According to this, accurate and consistent interpretation of sequence variants is essential for effective clinical care for individuals and their families with HCM.

With this regard, the 2015 guidelines from the American College of Medical Genetics and Genomics and the Association for Molecular Pathology (ACMG/AMP) were widely applicable, but several elements lacked specificity for given genes or diseases. The latter guideline was adapted for the most frequent causative HCM gene, the beta myosin heavy chain gene (MYH7) by the ClinGen (Clinical Genome Resource) expert panel, the Inherited Cardiomyopathy Expert Panel. Due to the adaptation, the guideline became gene-specific, with general considerations which are widely adaptable for most of the causative genes in HCM. Based on the modified guideline, web-based interpretation algorithms have been developed which integrate data from population databases and define pathogenicity of different variants independent of the observer, therefore aiding standardized clinical interpretation of genetic testing. The latter approach serves as a basis for recommendation for genetic testing in the recent ACC/ AHA HCM guideline published in 2020.

The current review is meant to compile the latest advances in HCM genetic testing in clinical practice, while bringing into focus some of the ongoing challenges clinical geneticists are still facing. Although nowadays the interpretation of genetic findings is two steps closer to a more accurate approach due to gene adaptation and automatization, the multitude of putative causative genes have been once again reduced to the 8 sarcomere genes, a backward step.

Keywords: hypertrophic cardiomyopathy, genetic testing, variant interpretation, gene curation, automatic web tools 


\section{Genetikai diagnózis hipertrófiás cardiomyopathiában: két lépést előre, egy lépést hátra}

A kifejezett genetikai heterogenitást mutató hipertrófiás cardiomyopathia (HCM) az egyik leggyakoribb monogénes kardiovaszkuláris betegség a világon. A betegség genetikai hátterének feltérképezésében nemrégiben alkalmazni kezdett új generációs szekvenálás a korábbiakban ismertnél jóval kifejezettebb genetikai variábilitásra derített fényt. Utóbbi nélkülözhetetlenné teszi a HCM-et feltételezhetően okozó genetikai variánsok pontos és konzisztens interpretálását, a genetikai variánsok standardizált megítélését, amely alapvető fontosságú a HCM-ben szenvedő betegek és családtagjaik klinikai megítélése szempontjából.

Fenti célból az American College of Medical Genetics and Genomics és az Association for Molecular Pathology (ACMG/ AMP) által 2015-ben publikált variáns interpretálási ajánlás széles körben használható volt, de egyes elemei nélkülözték a konkrét betegségekre, illetve génekre specifikus alkalmazhatóságot. Utóbbira a HCM-et okozó egyik leggyakoribb kóroki gén, a béta-miozin nehézlánc-gén (MYH7) vonatkozásában a ClinGen (Clinical Genome Resource) szakértői panelje, az Inherited Cardiomyopathy Expert Panel adaptálta az eredeti ACMG/AMP-ajánlást. Az adaptáció következtében az ajánlás jórészt génspecifikussá vált, olyan általános szempontrendszer kidolgozásával, amely gyakorlatilag az összes HCM-ben ismert kóroki génre alkalmazható. A módosított ajánlás alapján olyan webalapú variáns interpretálási algoritmusok kerültek kidolgozásra, amelyek nagy populációs adatbázisok integrálásával, a vizsgálótól függetlenül ítélik meg az egyes variánsok patogenitását, elősegítve ezzel a genetikai vizsgálatok eredményeinek standardizált klinikai interpretálhatóságát. Utóbbi alapján került megfogalmazásra a genetikai tesztelés algoritmusa a 2020-as ACC/ AHA HCM-ajánlásban.

Jelen összefoglaló közlemény a HCM genetikai tesztelésével kapcsolatos legújabb eredményeket foglalja össze, hangsúlyozva a még nyitott kérdéseket is. A HCM genetikája a variáns interpretáció standardizálásával és automatizálásával két lépést tett előre, de úgy látszik, hogy további, egyértelmű kóroki gént a legújabb technikákkal sem lehet már találni. Sőt, a biztosan kóroki gének száma szakértői panel véleményezése alapján összesen nyolc sarcomer génben határozható meg.

Kulcsszavak: hipertrófiás cardiomyopathia, genetikai tesztelés, variáns interpretáció, automata webalkalmazás

\section{Introduction}

Hypertrophic cardiomyopathy (HCM) is the most common genetic cardiovascular disorder worldwide with a prevalence of 1 in 500 in the general population (1). The disease is characterized by unexplained left ventricular hypertrophy (LVH) in the absence of other cardiac or non-cardiac conditions that could produce hypertrophy of similar proportions, with a wide array of clinical manifestations and hemodynamic abnormalities (2). Typical pathological features of the condition include hypertrophy, fibrosis and cardiomyocyte disarray. However, $\mathrm{HCM}$ can be phenotypically heterogeneous and manifest with mild LVH, concentric LVH and without some of these typical characteristics, though retaining the increased risk for sudden death (3).

HCM was first recognized over 50 years ago as a familial myocardial disease with increased risk for sudden death, variable disease expressivity, and natural history. After more than 2 decades during which the cause of HCM remained unknown, the dawn of a molecular era arrived in 1989, when HCM was first mapped to a genetic locus on chromosome 14 by linkage analysis and mutations in the beta-myosin heavy chain gene (MYH7) was strongly associated with disease for the first time (5). Since then, variants in several other genes encoding proteins of the cardiac sarcomere (MYBPC3, TNNT2, TPM1, MYL2, MYL3, TNNI3, and ACTC1) have been linked to HCM by multiple linkage studies in large pedigrees. Genetic testing throughout the years revealed $40-60 \%$ chance of identifying disease-causing variants in $\mathrm{HCM}$ patients diagnosed on clinical grounds, with a large predominance of pathogenic variants in these eight genes (6). The present paper compiles the latest updates on HCM genetic testing in clinical practice, while shedding light on some of the ongoing challenges clinical geneticists are still facing.

The advent of next-generation sequencing (NGS) facilitated the genetic investigation of heterogeneous disorders such as $\mathrm{HCM}$, leading to a rapid expansion in the number of non-sarcomeric genes included in a typical diagnostic gene panel. At that time, whenever a protein-altering variant was observed in an individual, the absence of that particular variant in controls was often used as stand-alone evidence for pathogenicity, although little evidence could be provided from segregation and functional studies. If in those times that was sufficient, nowadays more substantial evidence is necessary to prove the association between variants in a given gene and disease. Consequently, a decade ago, the promise of identifying new genes to explain gene-negative $\mathrm{HCM}$ cases was the driver of nume- 
rous candidate gene studies (7). Thus, a tremendous amount of candidate causative genes (more than 64) was proposed between 2000 and 2015 (8).

\section{Clinical validity of HCM genes in genetic testing}

The development of DNA-based testing of patients with $\mathrm{HCM}$ can aid in diagnosis and management of patients, and permit cascade screening of families. However, genetic testing for $\mathrm{HCM}$ is not as straightforward as it might at first appear, as several issues, particularly related to the interpretation of findings, limit the usefulness of this test (4).

Over time, due to joined efforts from population databases of whole-exome sequencing (WES) and partly the whole-genome sequencing (WGS) projects, many variants previously associated with cardiomyopathies were found to be rather likely benign on account of increased frequency in the population (9). Given the uncertain associations of non-sarcomeric genes with $\mathrm{HCM}$, a novel approach has been developed to help deciding which genes to include in the diagnostic panels in clinical practice. Diagnostic effectiveness (Deff), a gene- and disease-specific score, provides information on a gene's potential for family screening and the effective likelihood of pathogenicity of its variation when found in affected patients (6). The conclusion would be that expanded panels offer limited additional sensitivity, although it helps with the systematic screening of HCM-mimic genes.

Based on the considerations detailed above, thorough disease-specific gene curation is essential in dealing with a highly heterogeneous Mendelian disease like HCM. In a systematic approach to assess the validity of reported gene-disease associations, 57 genes were selected for curation. Eventually the proposed genes were classified into different categories: 8 genes were designated as definitive causative genes (the core sarcomeric genes previously considered as classic): $M Y B P C 3, M Y H 7$, TNNT2, TPM1, MYL2, MYL3, TNNI3, and ACTC1 (Table 1.) and 3 genes were found to have moderate evidence for disease causation: CSRP3, TNNC1 and JPH2. Sixteen other genes had limited evidence, and six genes had no evidence at all for disease causation (7).

Thus, current diagnostic gene panels should include genes considered to have a definitive or strong evidence of disease association to minimize the risk of inconclusive findings. When it comes to moderately associated genes, caution may be required as they may be considered causative if there is very clear supportive evidence of a functional or damaging effect for the variant. The genes with limited or no evidence for disease causation can be included only in segregation studies when a large pedigree may elucidate the VUS variant in a proband (7).
TABLE 1. Genes proven to have a definitive role for disease causation in isolated hypertrophic cardiomyopathy

\begin{tabular}{l|l}
\hline Gene & ClinGen classification \\
\hline MYBPC3 & Definitive (isolated HCM) \\
\hline MYH7 & Definitive (isolated HCM) \\
\hline MYL2 & Definitive (isolated HCM) \\
\hline MYL3 & Definitive (isolated HCM) \\
\hline TNNI3 & Definitive (isolated HCM) \\
\hline TNNT2 & Definitive (isolated HCM) \\
\hline TPM1 & Definitive (isolated HCM) \\
\hline
\end{tabular}

ACTC1: actin alpha cardiac muscle 1; MYBPC3: myosin binding protein C 3; MYH7: myosin heavy chain 7; MYL2: myosin light chain 2; MYL3: myosin light chain 3; TNNI3: troponin I3, cardiac type; TNNT2: troponin T2, cardiac type; TPM1: tropomyosin 1

\section{HCM mimics}

Several other genetic conditions that are not caused by cardiac sarcomere mutations have been associated with severe LVH and its associated consequences. These conditions are referred to as HCM phenocopies and include a variety of systemic or metabolic disorders that mimic HCM such as glycogen storage disorders, lysosomal storage disorders, mitochondrial cytopathies, cardiac amyloidosis and disorders of fatty acid metabolism. These conditions differ significantly from $\mathrm{HCM}$ due to sarcomeric mutations in terms not only of pathogenesis of hypertrophy but also of clinical features, prognosis, and most importantly, specific treatment (10).

The inclusion of the phenocopy genes (GAA, GLA, LAMP2, PRKAG2 and TTR) in diagnostic panels is recommended since it can aid with the differential diagnosis, treatment decision and more personalized approach (Table 2.). When causative variants in the syndromic genes are identified, concordance with the extracardiac phenotype features is important (Table 2.) (7).

The two extremes, either being more inclusive or less inclusive within the gene panels carry certain risks. While in the first option the possibility of getting false positive results is higher, in the latter may lead to false negative genetic tests (8).

In addition to current genetic testing strategies, future prospects encompass WGS (whole genome sequencing - complete sequencing of the entire genome in an individual) and WES (whole exome sequencingsequencing of the $1 \%$ of the protein-coding genome). While they might not be cost-effective in clinical practice, they offer the advantage, in comparison to a restricted gene panel, of screening specific genes known to yield interpretable variants. WGS can be particularly useful in detecting CNVs (copy number variants) and protein-truncating variants that are the leading cause of haploinsufficiency such as in MYBPC3 gene. For now, 
TABLE 2. Genes proven to have a definitive role for disease causation in hypertrophic cardiomyopathy associated with syndromic conditions

\begin{tabular}{|c|c|}
\hline Gene & ClinGen classification \\
\hline CACNA1C & Definitive (Timothy syndrome - syndromic conditions where isolated HCM may be seen) \\
\hline CAV3 & $\begin{array}{l}\text { Definitive (Caveolinopathy - syndromic conditions where left-ventricular hypertrophy is seen only with overt } \\
\text { systemic features) }\end{array}$ \\
\hline CRYAB & $\begin{array}{l}\text { Definitive (Alpha-B crystallinopathy - syndromic conditions where left-ventricular hypertrophy is seen only with } \\
\text { overt systemic features) }\end{array}$ \\
\hline DES & Definitive (Desminopathy - syndromic conditions where isolated HCM may be seen) \\
\hline FHL1 & Definitive (Emery-Dreifuss muscular dystrophy - syndromic conditions where isolated HCM may be seen) \\
\hline$F X N$ & $\begin{array}{l}\text { Definitive (Friedrich ataxia - syndromic conditions where left-ventricular hypertrophy is seen only with overt } \\
\text { systemic features) }\end{array}$ \\
\hline$G A A$ & $\begin{array}{l}\text { Definitive (Pompe disease - syndromic conditions where left-ventricular hypertrophy is seen only with overt } \\
\text { systemic features) }\end{array}$ \\
\hline GLA & Definitive (Fabry disease - syndromic conditions where isolated HCM may be seen) \\
\hline LAMP2 & Definitive (Danon disease - syndromic conditions where isolated HCM may be seen) \\
\hline$\angle D B 3$ & $\begin{array}{l}\text { Definitive (Myofibrillar myopathy - syndromic conditions where left-ventricular hypertrophy is seen only with overt } \\
\text { systemic features) }\end{array}$ \\
\hline MYO6 & $\begin{array}{l}\text { Definitive (Bilateral hearing loss - syndromic conditions where left-ventricular hypertrophy is seen only with overt } \\
\text { systemic features) }\end{array}$ \\
\hline PLN & Definitive (intrinsic cardiomyopathy gene - isolated $\mathrm{HCM}$ ) \\
\hline PRKAG2 & Definitive (PRKAG2 cardiomyopathy - syndromic conditions where isolated HCM may be seen) \\
\hline PTPN11 & Definitive (Noonan syndrome - syndromic conditions where isolated HCM may be seen) \\
\hline RAF1 & Definitive (Noonan syndrome - syndromic conditions where isolated HCM may be seen) \\
\hline RIT1 & Definitive (Noonan syndrome - syndromic conditions where isolated HCM may be seen) \\
\hline SLC25A4 & $\begin{array}{l}\text { Definitive (Mitochondrial disease - syndromic conditions where left-ventricular hypertrophy is seen only with overt } \\
\text { systemic features) }\end{array}$ \\
\hline TTR & Definitive (Transthyretin amyloidosis - syndromic conditions where isolated HCM may be seen) \\
\hline \multicolumn{2}{|c|}{$\begin{array}{l}\text { CACNA1C: calcium voltage-gated channel subunit alpha } 1 \mathrm{C} \text {; CAV3: caveolin 3; CRYAB: crystallin alpha B; DES: desmin; } \\
\text { FHL1: four and a half LIM domains 1; FXN: frataxin; GAA: alpha glucosidase; GLA: galactosidase alpha; } L A M P 2: \text { lysosomal } \\
\text { associated membrane protein 2; LDB3: LIM domain binding 3; MYO6: myosin VI; PLN: phospholamban; PRKAG2: protein kinase } \\
\text { AMP-activated non-catalytic subunit gamma 2; PTPN11: protein tyrosine phosphatase non-receptor type 11; RAF1: Raf-1 } \\
\text { proto-oncogene, serine/threonine kinase; RIT1: ras like without CAAX 1; SLC25A4: solute carrier family } 25 \text { member 4; } \\
\text { TTR: transthyretin }\end{array}$} \\
\hline
\end{tabular}

the main role of these strategies lies in identification of putative causative variants outside of known HCM genes.

The bottom line is that analysis should be initially focused on validated/curated HCM genes and if negative, it can be expanded to novel genes (with WGS and WES).

\section{Interpretation of genetic findings}

Accurate variant interpretation is a crucial and complex task in clinical practice, and it has been conducted, for almost two decades, by the American College of Medical Genetics and the Association of Molecular Pathologists (ACMG/AMP) (4). The current guidelines released in 2015 can be applied to all variants in all Mendelian genes. According to these recommendations, the variant interpretation should contain the evidence supporting the variant classification including its predicted effect on the respective protein and whether any vari- ant identified are likely to fully or partially explain the patient's indication for testing (11).

Based on certain essential criteria/databases such as population frequency data, computational and predictive (bioinformatics) data, segregation studies, de novo data, functional data, allelic data as well as other databases, the variants can be classified into 5 categories: pathogenic $(P)$, likely pathogenic $(L P)$, variant of unknown significance (VUS), likely benign (LB) and benign (B) (Figure 1).

According to the latest guidelines, the fine-tuning of variant interpretation can be achieved by following 8 types of evidence, each including 2 sets of criteria with different strengths in favor of a pathogenic or a benign role. First, a set of criteria is checked independently for each variant. Each criterion assessed a particular supporting evidence information, such as its frequency in population databases, in silico prediction of a protein damaging effect or co-segregation in family members. Criteria are grouped by different 


\begin{tabular}{|c|c|c|c|c|c|}
\hline & & $\begin{array}{l}\text { Population data } \\
\text { Compuational and predictive data } \\
\text { Functional data } \\
\text { Segregation data }\end{array}$ & $\begin{array}{l}\text { De novo data } \\
\text { Allele data } \\
\text { Other database } \\
\text { Other data }\end{array}$ & & \\
\hline Strong & Supporting & Supporting & Moderate & Strong & Very Strong \\
\hline $\begin{array}{l}\text { BS1: MAF too high } \\
\text { for disorder } \\
\text { BS2: observation in } \\
\text { controls incosist- } \\
\text { ent with disease } \\
\text { penetrance } \\
\text { BS3: in vivo/in vitro } \\
\text { functional studies } \\
\text { show no delet. } \\
\text { effect } \\
\text { BS4: non-segreg- } \\
\text { ration with disease }\end{array}$ & $\begin{array}{l}\text { BP1: missense in gene } \\
\text { where only truncating } \\
\text { cause disease } \\
\text { BP2: observed in trans } \\
\text { with a dominant variant } \\
\text { or in cis with a patho- } \\
\text { genic variant } \\
\text { BP3: in-frame delins in a } \\
\text { repetitive region witout a } \\
\text { known function } \\
\text { BP4: multiple lines of } \\
\text { computational evidence } \\
\text { suggest no impact on } \\
\text { gene } \\
\text { BP5: found in a case with } \\
\text { an alternate cause } \\
\text { BP6: reputable source w/ } \\
\text { out shared data = benign } \\
\text { BP7: silent variant with } \\
\text { non predicted slice } \\
\text { impact }\end{array}$ & $\begin{array}{l}\text { PP1: co-segregration } \\
\text { with disease in multiple } \\
\text { family members } \\
\text { PP2: missense in a gene } \\
\text { with low rate of benign } \\
\text { missense variants, } \\
\text { pathogenic missenses } \\
\text { common } \\
\text { PP3: multiple lines of } \\
\text { cumputational evidence } \\
\text { support delet. effect } \\
\text { PP4: patient's pheno- } \\
\text { type or family history } \\
\text { highly specific for gene } \\
\text { PP5: reputable source = } \\
\text { pathogenic }\end{array}$ & $\begin{array}{l}\text { PM1: located in } \\
\text { mutational hot spot } \\
\text { PM2: absent from } \\
\text { controls } \\
\text { PM3: detected in } \\
\text { trans with a patho- } \\
\text { genic variant } \\
\text { PM4: protein length } \\
\text { changes due to } \\
\text { frame shifts } \\
\text { PM5: novel missense } \\
\text { change at a codon } \\
\text { level known to be } \\
\text { pathogenic } \\
\text { PM6: de novo, } \\
\text { without confirmed } \\
\text { parenthood }\end{array}$ & $\begin{array}{l}\text { PS1: same AA change } \\
\text { as a known patho- } \\
\text { genic variant } \\
\text { PS2: de novo (with } \\
\text { parenthood con- } \\
\text { firmed) } \\
\text { PS3: in vivo/in vitro } \\
\text { functional studies } \\
\text { PS4: increased } \\
\text { prevalance in af- } \\
\text { fected individual vs. } \\
\text { controls }\end{array}$ & $\begin{array}{l}\text { PVS1: null variant in } \\
\text { a gene where LOF is } \\
\text { a known mechanism } \\
\text { of disease }\end{array}$ \\
\hline
\end{tabular}

FIGURE 1. Criteria for classifying varints by the type of evidence as well as the strength of the criteria for a benign (left side) or pathogenic (right side) assertion. Abbreviations: BS, benign strong; BP, benign supporting; LOF, loss-of-function; MAF, minor allele frequency; AA, aminoacid; PM, pathogenic moderate; PP, pathogenic supporting; PS, pathogenic strong; PVS, pathogenic very strong. Figure adapted from: Richards S, Aziz N, Bale S, et al. Standards and guidelines for the interpretation of sequence variants: A joint consensus recommendation of the American College of Medical Genetics and Genomics and the Association for Molecular Pathology. Genet Med 2015; 17(5): 405-424. doi:10.1038/gim.2015.30

levels of evidence and by pathogenic/benign classes. Finally, a set of rules combines the evaluated criteria and classifies a variant accordingly to the final ACMG/ AMP 5-tier system.

\section{Beta-myosin heavy chain gene (MYH7) standardized variant interpretation}

The beta myosin heavy chain gene (MYH7) is one of the most frequently tested genes in a clinical setting since it is a major contributor to several cardiomyopathies (HCM, DCM, RCM) (2). Although the ACMG/AMP guideline framework represents a major step forward for variant classification in the context of Mendelian disease, it needs constant improvement and refinement as the understanding of these diseases develops. The lack of standardization has led over time to numerous interpretation differences in ClinVar database, mostly misclassifications, which can have serious consequences in medically actionable variants.

In 2017, the ClinGen (Clinical Genome Resource) has established expert panels to adapt the ACMG/AMP for specific genes and diseases. The Inherited Cardiomyopathy Expert Panel (CMP-EP) selected MYH7 as a pilot gene to develop guidelines adaptation for its variants. To achieve this goal, an expert task team of clinicians and medical molecular geneticists from 3 different institutions reviewed the original ACMG/AMP framework and developed proposed changes to adapt them for MYH7 (11). Their assignment was as follows: to select 60 representative $M Y H 7$ variants, to test and apply as many rules as possible to them, to cover a range of classifications, and to include discrepant ClinVar assertions.

They realized that out of the original 28 ACMG/AMP rules, 9 were not applicable and another 12 required disease- and/or gene-specific adjustments. In 5 rules the 
strength criteria were modified. Four rules of the pathogenic framework (PVS1, PM3, PP2, PP4, see in Figure 1) and 3 rules of the benign framework (BS2, BP1, BP3, see in Figure 1) were evaluated as not applicable either entirely or in the original strength level suggested. PVS1 (since null variants are not a known mechanism for disease, loss of function variants being very rare and their contribution to inherited cardiomyopathy is incompletely understood) has been downgraded to PVS1_Moderate evidence. Two additional rules are not applicable: PP5/ BP6 (reputable source reports variant as pathogenic/ benign, but evidence is not accessible) (15).

The main adaptations to the classic rules are concerning the minor allele frequency-driven rules (BA1, BS1, and PM2, see in Figure 1). They were found to be overly conservative such as BA1 criterion (the allele frequency threshold above which a variant is considered benign). For many Mendelian conditions, the default threshold of $5 \%$ is way higher than it needs to be.

Furthermore, regarding the segregation with disease (PP1, PP1_Moderate, PP1_Strong), the original framework contains several areas of vagueness (such as the absence of quantitative guidance for increasing the weight depending on the extent of "segregation with disease"). The CMP-EP specified three levels of evidence using autosomal dominant likelihood ratios of 10 (3 meioses), 30 (5 meioses), and 100 (7 meioses) to count as supporting, moderate, and strong evidence provided that PM2 (absent or rare in large population cohorts) is met. Finally, the CMP-EP waived the ACMG/ AMP recommendation for demonstrating segregation in more than one family given that $\mathrm{MYH7}$ is a well-established cardiomyopathy gene.

For the rules addressing the increased prevalence of variant in probands versus controls (PS4, PS4_Moderate, PS4_Supporting) the conservative universal thresholds were set to proband counts of $\geq 2$ (supporting), $\geq 6$ (moderate), and $\geq 15$ (strong) for the sake of simplification. To apply these rules, PM2 criterion (absent/extremely rare, $<0.004 \%$, from large population studies) must be met.

PS2 rule (see in Figure 1) concerning occurrence of de novo variants has also been modified by removing the necessity of maternity confirmation in a patient. Also, when paternity has not been established, de novo occurrence receives moderate weight (PM6) but the CMP-EP allowed upgrading it to "strong" (PS2) when at least 3 de novo occurrences have been reported.

The ACMG/AMP framework assigns strong weight to well-established in vitro or in vivo functional studies that are supportive of a damaging effect on the gene or protein (PS3). However, in vivo studies are not realyly feasible for $M Y H 7$ gene while the in vitro ones are less conclusive and currently not considered strong evidence. Nevertheless, the CMP-EP recognized that as soon as in vitro models (that accurately predict the effect in vivo) become available, their weight can be reconsidered.

The protein domain related rules were also affected. Whereas the ACMG/AMP framework assigns supporting evidence of pathogenicity to missense variants in a gene that has a low rate of missense variation and moderate evidence for variants located in a hotspot and/or critical domain without benign variation (PM1), it has been well established that missense variants in $\mathrm{MYH7}$ are the predominant class of pathogenic alleles.

Consequently, by applying the original rules to the 60 pilot variants covering a wide range of scenarios, the experts found that 8 out of them have been misclassified, stressing on the importance of framework standardization and data sharing (15).

\section{Automatic web tools for variant classification}

The implementation of ACMG/AMP guidelines for variant interpretation can be cumbersome for each individual patient because of the complexity of criteria that need to be evaluated over a large set of variants. Therefore, informatics tools (web calculators) have been developed to aid in the process in clinical settings. They allow the user to select the criteria verified by the variant of interest, and then they automatically compute the final classification (16). One example would be the ClinGen Pathogenicity Calculator that provides supporting data to reach more definitive conclusion. However, web calculators lack automatization of the entire ACMG/AMP system and fail to interpret a large set of variants per patient.

ACMG/AMP guidelines was needed to solve complexity and reproducibility aspects over manual application (17). Several automatic tools have been developed in the last couple of years: InterVar, allowing the interpretation of multiple variants occurring in any Mendelian genes, (18) CardioClassifier that interprets variants occurring in 40 genes associated with cardiovascular disease (19) and CardioVAl (20), a web tools that supports genomic variant classification according to ACMG/AMP rules.

CardioClassifier (https://www.cardioclassifier.org) was developed by the Cardiovascular Genetics and Genomics team of the Imperial College, London. The tool is designed to facilitate variant interpretation across a wide range of inherited cardiac conditions. It integrates data retrieved from multiple sources through an interactive interface to support variant interpretation. Combining disease- and gene-specific knowledge with variant observation in large cohort of cases and controls, computational ACMG criteria have been refined. This tool is transparent, generates fast, reproducible and interactive variant pathogenicity reports. It displays all the information along with the final classification. 
Developed by University of Pavia, Italy, CardioVAI (Cardio Variant Interpreter) (http://cardiovai.engenom.com) is a web tool that automatically classify genomic variants in heritable cardiac disorders related genes according to ACMG/AMP 5-tier class, showing supporting evidence in terms of activated guidelines criteria. Relevant information was retrieved from public databases such as ClinVar, MedGen, ExAc, Disease Ontology and Orphanet (21). The tailored, specific information such as genotype-phenotype correlation and hotspot domains are also incorporated. The generated pathogenicity score is assigned to highlight VUS variants as possible candidates for a further assessment. With a specificity of $97.08 \%$ and an average sensitivity of $74.8 \%$, CardioVAl ranks the best among the other similar tools (InterVar and CardioClassifier), reducing the number of VUS to $70.9 \%$. Compared to them, CardioVAl evaluates better criteria like PS1, PP5 and BP6 and incorporates recent refined data for $\mathrm{MYH7}$ gene variants interpretation. It incorporates disease specific knowledge gathered from omics-resources and CMP-EP guidelines adaptation for MYH7 variants. Additional validation on $60 \mathrm{MYH7}$ variants reports a classification concordance of $93.4 \%$, showing the importance of population-database selection for the evaluation of criteria such as BS1 and PM2 (20).

Due to gene curation efforts from ClinGen and automated variant interpretation webtools such as CardioClassifier and CardioVai great progress has been achieved, minimizing the risk of false-positive results. This, in turn, may increase the false negative result rate. Recently, in HCM, since functional studies are limited and the disease is highly heterogeneous, around $8 \%$ of HCM patients are genetically misclassified as VUS variant carriers when, in fact, they may have a rather pathogenic one. These issues can be overcome by data sharing within international centers that would be beneficial particularly in cases of encountering interesting founder, endemic variants. Such opportunity already exists (the ShaRe registry, https://theshareregistry. org) with the main goal of sharing knowledge between different centers through ClinVar database. For example, using shared data, understandings like the one in which patients with $\mathrm{MYH7}$ variants had a higher risk of advanced heart failure and worse outcome comparing with MYBPC3 gene cohort have become available (8). Worth mentioning is also the fact that patients with complex genotypes carrying 2 pathogenic variants are at greater risk of adverse outcome and SCD, regardless of the genes involved.

Regarding the genetic interpretation of novel variants, recent study suggests that, when found in a patient confirmed to have disease, the novel rare variants in established HCM-related genes are empirically shown to have a sufficiently high probability of pathogenicity to support a "likely pathogenic" classification, even without additional segregation or functional data. This could increase the yield of high confidence actionable variants, consistent with the framework and recommendations of current guidelines (12).

\section{Targeted gene testing in $\mathrm{HCM}$}

Although current diagnosis of HCM is solely based on clinical findings, genetic diagnosis of $\mathrm{HCM}$ provides very important additional information. According to this, genetic testing is recommended in patients fulfilling diagnostic criteria for $\mathrm{HCM}$, when it enables cascade genetic screening of their relatives. Genetic screening strategy in $\mathrm{HCM}$ is summarized in Figure 2. Genetic testing for HCM is first initiated in an individual with a clear-cut diagnosis of $\mathrm{HCM}$, usually in the index case. If a definitive likely pathogenic (LP) or pathogenic $(P)$ variant is found, then cascade genetic testing in relatives can be initiated. Demonstration of a VUS in a proband is not a clinically actionable result. In selected circumstances, family member testing may be undertaken, at either a clinical or research level, to further elicit the pathogenicity of the variant (e.g., through cosegregation analysis in family members, determine de novo status through parental testing, etc.). However, this is most appropriate in the setting of guidance from a cardiovascular genetics expert. If genetic testing does not identify a pathogenic variant in a patient with HCM (i.e., only identifies benign/likely benign variants), there is no indication to do genetic testing in family members as the identification of such variants will not change clinical management, including the need for continued clinical screening. In genotype-negative relatives of individuals with genotype-positive HCM, no further clinical follow-up is required. Over time, as more knowledge is gained, some variants previously thought to be likely pathogenic or pathogenic may be downgraded to a VUS or benign category. In such instances, family relatives who were released from clinical surveillance on the basis of the previous gene result need to be notified and regular clinical screening recommenced (3).

\section{Interpretation of genotype-negative HCM}

In general, those patients lacking pathogenic variants in the 8 definitive sarcomeric genes have a better clinical outcome compared to the variant-positive ones. Ingles et al described nonfamilial HCM occurring in $40 \%$ of studied cohort with distinct phenotype from genotype-positive cases. However, that should not discourage clinicians to regularly monitor the family members as well, since HCM is known for its high variability in terms of age of onset and phenotype severity $(13,3)$. 


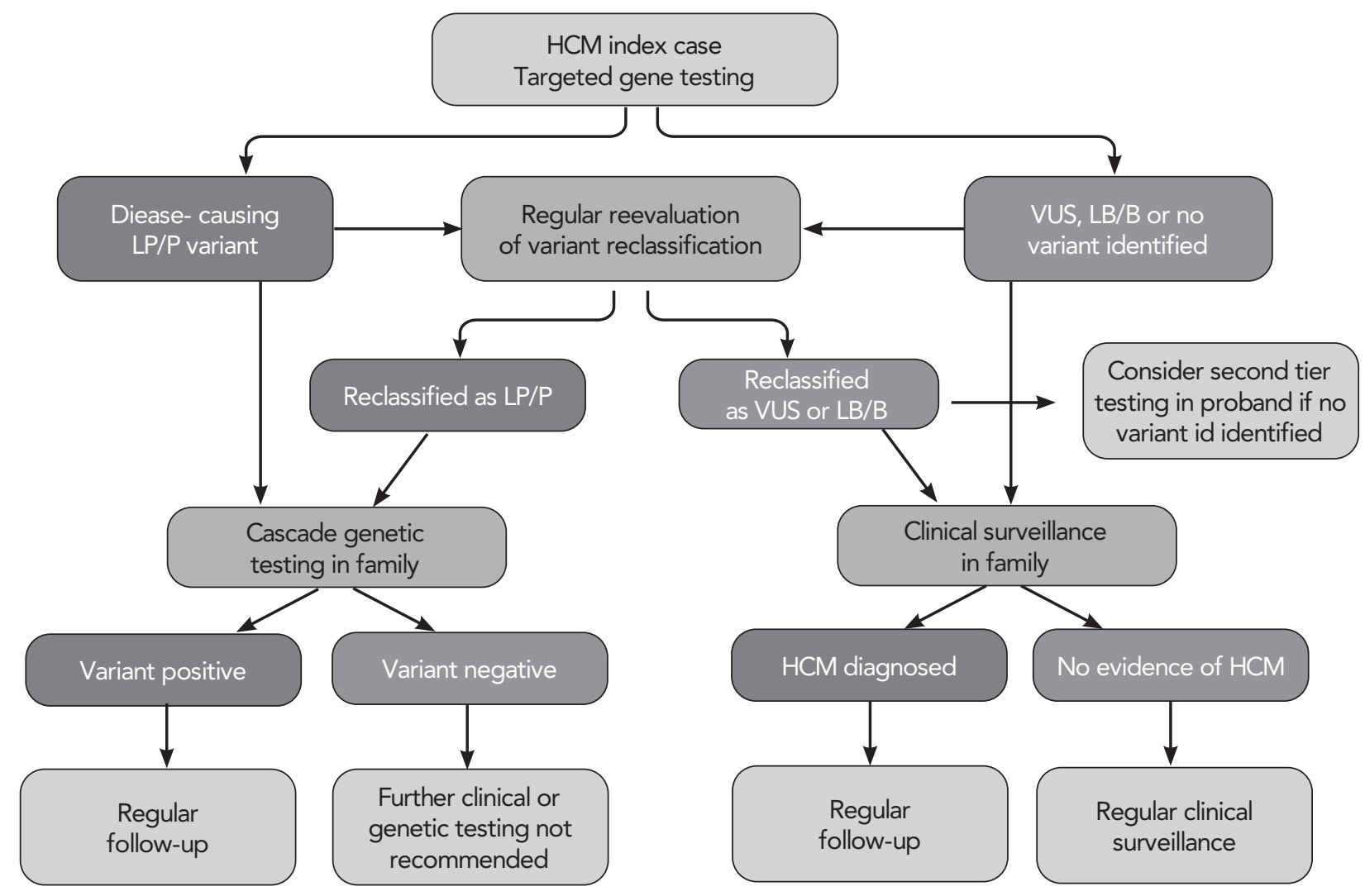

FIGURE 2. Flowchart for genetic testing process in HCM. HCM: hypertrophic cardiomyopathy; LB/B, likely benign/benign; LP/P, likely pathogenic or pathogenic; and VUS, variant of unknown significance. Figure adapted from: Ommen SR, Mital S, Burke MA, et al. 2020 AHA/ACC guideline for the diagnosis and treatment of patients with hypertrophic cardiomyopathy: a report of the American College of Cardiology/American Heart Association Joint Committee on Clinical Practice Guidelines. J Am Coll Cardiol 2020; 76 : e159-240.

\section{Conclusion and future perspectives}

Although nowadays the interpretation of genetic findings is two steps closer to a more accurate approach due to gene adaptation and automatization, the multitude of putative causative genes have been once again reduced to the 8 sarcomere genes, a backward step.

$\mathrm{HCM}$ remains basically a disease of the sarcomere, characterized by incomplete penetrance and highly variable phenotypic expressivity, with an increased rate $(40-60 \%)$ of negative-genotype. This indicates that other genetic and epigenetic factors (like obesity and hypertension) may contribute to the development of disease. Other genetic factors may include common, low frequency, rare variants that can play a protective or modifier role (14). Such factors can be identified via large-scale genome-wide association studies and WGS, followed by integration of their genetic profile with the specific nongenetic ones.

Current genetic testing strategies rely on more restricted gene panels with proven, definitive association with $\mathrm{HCM}$. Studies have shown that new, additional putative genes are accounting for only a limited number of cases $(8,3)$.
The presence of multiple rare genetic variants in an individual has a cumulative effect on clinical phenotype and prognosis, irrespective of variant pathogenicity, suggesting that variants that are non-damaging separately may play a modifying role in conjunction with other variants.

Further, three challenges still remain: the lack of optimal accuracy of variant interpretation, the lack of clear genotype-phenotype correlations and the need of expanding research on genetic causes of HCM beyond the monogenic Mendelian inheritance model.

\section{Acknowledgements}

This work was supported by grants GINOP- 2.3.2-152016-00039 (,Ritka betegségek patogenezisének kutatása, új diagnosztikai és terápiás eljárásokat megalapozó fejlesztések”), GINOP-2.3.2-15-2016-00048 („Életet veSzélyezTető Akut megbetegedések súlYossági és hALálozási mutatólnak jaVitása transzlációs orvostudományi mEgközelitésben - STAY ALIVE”) and the „Hetényi Géza" Research Fund of the Faculty of Medicine of the University of Szeged. 


\section{REFERENCES}

1. Maron BJ, Gardin JM, Flack JM, Gidding SS, Kurosaki TT, Bild DE. Prevalence of Hypertrophic Cardiomyopathy in a General Population of Young Adults. Circulation 1995; 92(4).

https://doi.org/10.1161/01.CIR.92.4.785

2. Marian AJ, Braunwald E. Hypertrophic Cardiomyopathy: Genetics, Pathogenesis, Clinical Manifestations, Diagnosis, and Therapy. Circ Res 2017; 121(7): 749-770.

https://doi.org/10.1161/CIRCRESAHA.117.311059

3. Ommen SR, Mital S, Burke MA, et al. 2020 AHA/ACC Guideline for the Diagnosis and Treatment of Patients With Hypertrophic Cardiomyopathy. Vol 142; 2020.

https://doi.org/10.1161/cir.0000000000000937

4. Ackerman MJ, Priori SG, Willems S, et al. HRS/EHRA expert consensus statement on the state of genetic testing for the channelopathies and cardiomyopathies this document was developed as a partnership between the Heart Rhythm Society (HRS) and the European Heart Rhythm Association (EHRA). Hear Rhythm 2011; 8(8): 1308-1339. https://doi.org/10.1016/j.hrthm.2011.05.020

5. Jarcho JA, McKenna W, Pare JA, et al. Mapping a gene for familial hypertrophic cardiomyopathy to chromosome 14q1. N Engl J Med 1989;3 21(20): 1372-1378.

https://doi.org/10.1056/NEJM198911163212005

6. Mazzarotto F, Girolami F, Boschi B, et al. Defining the diagnostic effectiveness of genes for inclusion in panels: the experience of two decades of genetic testing for hypertrophic cardiomyopathy at a single center. https://doi.org/10.1038/s41436

7. Ingles J, Goldstein J, Thaxton C, et al. Evaluating the Clinical Validity of Hypertrophic Cardiomyopathy Genes. Circ Genomic Precis Med 2019; 12(2): 57-64. https://doi.org/10.1161/CIRCGEN.119.002460 8. Mazzarotto F, Olivotto I, Boschi B, et al. Contemporary Insights Into the Genetics of Hypertrophic Cardiomyopathy: Toward a New Era in Clinical Testing? J Am Heart Assoc 2020; 9(8): e015473. https://doi.org/10.1161/JAHA.119.015473

9. Golbus JR, Puckelwartz MJ, Fahrenbach JP, Dellefave-Castillo LM, Wolfgeher D, McNally EM. Population-based variation in cardiomyopathy genes. Circ Cardiovasc Genet 2012; 5(4): 391-399. https://doi.org/10.1161/CIRCGENETICS.112.962928

10. Lopes LR, Zekavati A, Syrris P, et al. Genetic complexity in hypertrophic cardiomyopathy revealed by high-throughput sequencing. J Med Genet 2013; 50(4): 228-239.

https://doi.org/10.1136/jmedgenet-2012-101270

11. Richards S, Aziz N, Bale S, et al. Standards and guidelines for the interpretation of sequence variants: A joint consensus recommendation of the American College of Medical Genetics and
Genomics and the Association for Molecular Pathology. Genet Med 2015; 17(5): 405-424. https://doi.org/10.1038/gim.2015.30

12. Walsh R, Mazzarotto F, Whiffin N, et al. Quantitative approaches to variant classification increase the yield and precision of genetic testing in Mendelian diseases: The case of hypertrophic cardiomyopathy. Genome Med 2019; 11(1).

https://doi.org/10.1186/s13073-019-0616-z

13. Ingles J, Burns C, Bagnall RD, et al. Nonfamilial Hypertrophic Cardiomyopathy: Prevalence, Natural History, and Clinical Implications. Circ Cardiovasc Genet 2017; 10(2).

https://doi.org/10.1161/CIRCGENETICS.116.001620

14. Harper AR, Goel A, Grace C, et al. Common genetic variants and modifiable risk factors underpin hypertrophic cardiomyopathy susceptibility and expressivity. Nat Genet 2021; 53(2): 135-142.

https://doi.org/10.1038/s41588-020-00764-0

15. Kelly MA, Caleshu C, Morales A, et al. Adaptation and validation of the ACMG/AMP variant classification framework for MYH7-associated inherited cardiomyopathies: Recommendations by ClinGen's Inherited Cardiomyopathy Expert Panel. Genet Med 2018; 20(3): 351-359. https://doi.org/10.1038/gim.2017.218

16. Patel RY, Shah N, Jackson AR, et al. ClinGen Pathogenicity Calculator: a configurable system for assessing pathogenicity of genetic variants. Genome Med 2017; 9(1): 3 https://doi.org/10.1186/s13073-016-0391-z

17. Amendola LM, Jarvik GP, Leo MC, et al. Performance of ACMGAMP Variant-Interpretation Guidelines among Nine Laboratories in the Clinical Sequencing Exploratory Research Consortium. Am J Hum Genet 2016; 98(6): 1067-1076.

https://doi.org/10.1016/j.ajhg.2016.03.024

18. Li Q, Wang K. InterVar: Clinical Interpretation of Genetic Variants by the 2015 ACMG-AMP Guidelines. Am J Hum Genet 2017; 100(2): 267-280. https://doi.org/10.1016/j.ajhg.2017.01.004

19. Whiffin N, Walsh R, Govind R, et al. CardioClassifier: diseaseand gene-specific computational decision support for clinical genome interpretation. Genet Med 2018; 20(10): 1246-1254.

https://doi.org/10.1038/gim.2017.258

20. Nicora G, Limongelli I, Gambelli P, et al. CardioVAl: An automatic implementation of ACMG-AMP variant interpretation guidelines in the diagnosis of cardiovascular diseases. Hum Mutat 2018; 39(12): 1835-1846. https://doi.org/10.1002/humu.23665

21. Kibbe WA, Arze C, Felix V, et al. Disease Ontology 2015 update: an expanded and updated database of human diseases for linking biomedical knowledge through disease data. Nucleic Acids Res 2015; 43(Database issue): D1071-8.

https://doi.org/10.1093/nar/gku1011 